\title{
Entrar na Igreja por outra Porta: Reflexões Eclesiológicas para os Dias de Hoje
}

\author{
Prof. Dr. Claudio de Oliveira Ribeiro ${ }^{1}$ \\ "O reino de Deus é semelhante ao fermento que uma \\ mulher tomou e escondeu em três medidas de farinha, \\ até ficar tudo levedado". (Lucas 13,18-19)
}

RESUMO

O artigo realça aspectos teológicos sobre a natureza, o sentido, a vida e a missão da Igreja, ao procurar oferecer uma visão panorâmica de questões consideradas fundamentais para o debate eclesiológico hoje, como as tensões entre Igreja e Reino de Deus, entre as dimensões eclesial e eclesiástica, o valor dos sacramentos e necessidade de renovação da vida. Após isso, nos propomos a apresentar um outro bloco de reflexão que analisa aspectos da vida eclesial, tendo em vista uma eclesiologia popular.

Palavras-chave: eclesiologia CEBs - koinonia - pastoral popular

\section{ABSTRACT}

The article enhances theologic aspects about the nature, the meaning, the life and churches mission, when searching to offer a panoramic vision of the quetions considered as the main ones for eclesiologic debates today, such as tention between church and The kingdom of God, between eclesial dimention and eclesiastic, the value of the sacraments and the need of life renewal. After this, we propose ourself to present another set of reflection which analyses eclesial aspect life, having in mind popular eclesiology.

Key-words: Eclesiology, CEBs (Base Small Christian Communities), Koinonia, Popular pastoral or popular service.

Claudio de Oliveira Ribeiro. Pastor metodista na comunidade de Jardim Santo André e professor de teologia da Universidade Metodista de São Paulo. 


\section{INTRODUÇÃO}

Pensar a Igreja não é tarefa das mais simples. As contradições que, historicamente, foram acumuladas em meio a uma riqueza incomensurável de vivência comunitária, solidária, libertadora e fraterna da fé, formam um quadro que no plano dos sentimentos e das intenções pessoais de milhões, criam até mesmo, relações de amor e de ódio. Daí a insistência de se "entrar na Igreja por outra porta".

O contexto brasileiro em particular e latino-americano em geral experimentaram nas últimas décadas do século $X X$, uma forte renovação eclesial. $O$ dado eclesiológico representou um aspecto crucial, sempre marcado por novas formulações e por intensos debates no contexto da teologia latinoamericana. Esta produção não ficou isenta de conflitos. Um fato exemplar foram as indagações, no início dos anos de 1980, do Magistério da Igreja Católica Romana às teses de Leonardo Boff em Igreja: Carisma e Poder. ${ }^{2}$ Mesmo entre os teólogos e pastoralistas latino-americanos, há tensões no que diz respeito a um certo "eclesiocentrismo" da produção teológica.

O fato é que a vida comunitária cada vez mais se impõe como um desafio para os cristãos, devido ao crescimento da cultura individualista gerada pelas formas e os novos estágios do sistema econômico. Em meio a isso, compreendemos que uma comunidade que vive na força do Espírito de Deus terá suas próprias características que, certamente, a distinguirão de outros esforços humanos, ainda que religiosos. A fé, como se sabe, transfigura o mundo e com esta nova visão, os cristãos sob a ação contínua e soberana de Deus, agem reconstruindo a vida e o mundo. São homens e mulheres, jovens, idosos e crianças que buscam uma nova forma de viver a fé e a vida.

Vivemos o tempo oportuno, o Kairós, para revisões de vida, de métodos de trabalho, de enfoques. Diferentes setores das igrejas - os que trabalham com populações empobrecidas, com jovens ou com outros grupos específicos - têm buscado novos rumos. Cabe-nos seguir, por atitude gratuita e de fé, a direção do vento do Espírito de Deus.

Reconhecemos que a Igreja é provisória, não obstante o seu forte conteúdo espiritual. Essas são perspectivas sistematizadas por renomados

2 Petrópolis-RJ, Vozes, 1981. 
teólogos do século XX, como Karl Barth, por exemplo. Nestas linhas, estas idéias, ainda que modestamente, estão presentes como referência teológica fundamental. Ao lado delas, encontram-se outras que constituem um universo de vivência pessoal e pastoral. Trata-se de uma experiência de quase três décadas vivida de forma intensa e apaixonada.

O interesse pela reflexão eclesiológica me acompanha há tempos. ${ }^{3}$ Nestas páginas, aproveito para partilhar, sobretudo nas indicações bibliográficas presentes nas 'notas', por isso elas são extensas, um pouco do que tenho refletido sobre temas teológicos afins. A eclesiologia como área sistemática é a que talvez mais se aproxime da teologia pastoral. Para essa análise, nos propomos a apresentar dois blocos de reflexões. O primeiro apresenta marcas e pressupostos para o estudo preliminar da eclesiologia, as quais venho me detendo na tarefa docente. O segundo pólo de reflexões analisa aspectos da vida eclesial, tendo em vista uma eclesiologia popular.

\section{I - IDENTIDADE E PRESSUPOSTOS PARA O ESTUDO DA ECLESIOLOGIA HOJE}

A eclesiologia, como reflexão bíblico-teológica sobre a natureza, o sentido, a vida e a missão da Igreja, procura oferecer respostas aos referidos aspectos, levando em conta os desafios que o tempo presente traz. Em outras palavras, diríamos que a identidade e a relevância da eclesiologia dá-se basicamente, a partir da seguinte questão: "como reconhecer o amor de Deus por intermédio da vivência eclesial e eclesiástica?"

Mais do que a concepção grega de ekklesia (assembléia, expressão política do povo), o Novo Testamento (=NT), com a diversidade de modelos

3 Sob perspectivas teológicas distintas da que agora trato, veja outras reflexões eclesiológicas que apresentei em: "Comunidade e massa: tensões, contradições e desafios para as igrejas". Estudos Bíblicos (55), 1997, pp. 9-28. Vozes/Sinodal; "Igreja como comunidade profética: uma perspectiva evangélica”. Estudos Teológicos, 37(1), 1997, pp. 62-72. Fac. Teologia da IECLB; "A provisoriedade da Igreja: uma contribuição teológica de Karl Barth". Fragmentos de Cultura, 8(2), mar/abr 1998, pp. 443-470. IFITEG; "Challenges for Mission: A Latin-American Protestant approach to the building of community life - as an understanding of mission - in the context of neoliberalism". Voices, XXIII (2), December 2000, pp. 97-151; "Por uma Eclesiologia Metodista Brasileira". Caminhando, IX(13), jan/jun 2004, pp. 43-64; e "A vida em comunidade como fonte de utopia: o diálogo de um pastor brasileiro com a Teologia de Paul Tillich". Caminhando, XI(17), set 2006, pp. 33-45.

ReVISTA de CultuRA TEOLÓGICA - V. 15 - N. 61 - out/DEZ 2007105 
eclesiológicos que possui, retratará com esse termo a concepção vétero-testamentária de qahal (assembléia, expressão cúltica e religiosa do povo) para referir-se à Igreja. Essa é a comunidade daqueles e daquelas que abraçaram a causa de Jesus (=Reino de Deus) e a testemunham, sob o poder do Espírito Santo, como um sinal de esperança para toda a humanidade. Ela, em sua versão explícita, é composta de homens e mulheres que acolhem, debatem e celebram a sua fé e estabelecem propósitos comuns de ação, centrados na celebração dos sacramentos e na leitura da Bíblia.

A Igreja, portanto, é de Deus, reunida pela eleição do Pai - (graça) -, edificada subjetivamente a partir da realização objetiva da reconciliação do mundo com Deus no Filho - (fé) - e enviada objetivamente por intermédio da realização subjetiva da reconciliação no Espírito Santo - (ação). Essa base trinitária da Igreja oferece formas mais adequadas de comunhão e de participação e dá ao ser humano um lugar de destaque, considerando o contexto de seus valores culturais, suas tradições e costumes.

Primeira pressuposição: As tensões entre lgreja, as igrejas e o Reino.

A Igreja não é o Reino de Deus, mas pode e deve ser porta-voz e testemunha do Reino, ao anunciar o querigma fundante e as exigências decorrentes dele. As ações da Igreja somente fazem sentido quando, sob a orientação do Espírito Santo, visam o bem estar integral do ser humano e de toda a criação.

A vida eclesial seguindo o padrão bíblico que realça as críticas proféticas provenientes tanto do AT como do NT está sempre fundamentada em tensões dialéticas que exigem e criam novas realidades. Nesse sentido, estão presentes na vida da Igreja as tensões entre o eclesial (dimensões mais vivas e criativas da vivência comunitária da fé cristã) e o eclesiástico (dimensões formais, jurídicas e institucionais da igreja). ${ }^{4}$

4 Bastante didática é a apresentação de Avery Dulles em A lgreja e seus Modelos (São PauloSP, Paulinas, 1974), quando foram bem divulgados os modelos de Igreja como Instituição, como Comunhão Mística, como Sacramento, como Aratuto e como Serva. O autor ainda apresenta sete critérios de avaliação desses modelos: 1. Base bíblica (pressupondo os esforços exegéticos). 2. Base na tradição. 3. Capacidade de dar aos membros da Igreja um sentido coletivo de sua identidade e missão. 4. Tendência a fomentar as virtudes e valores que histórica e geralmente são admirados e reconhecidos pelos/as cristãos. 5. Correspondência com a experiência religiosa das pessoas hoje. 6. Fecundidade teológica (pressupondo uma 
Da mesma forma, situam-se as tensões entre movimento \& instituição, fé \& religião, simbólico (que une/religa) \& diabólico (que separa) e outras similares. Tais tensões se não forem assumidas e refletidas incorrem a uma série de riscos. Entre os perigos estão: absolutizar condicionamentos históricos em nome de uma correta interpretação dos elementos fundantes (tradição sem reforma), efetuar uma crítica vazia pelo uso indevido, arbitrário e excessivo da liberdade (reforma sem tradição), relativizar de modo esvaziador o cerne da mensagem fundante (adaptação sem veracidade), não considerar a realidade cultural dos destinatários da mensagem (veracidade sem adaptação) ${ }^{5}$. As formas de culto e de governo das igrejas, por exemplo, devem ser permanentemente confrontadas com tais possibilidades para se aproximarem de seus objetivos e metas e responderem aos desafios da missão.

\section{Segunda pressuposição: as marcas tradicionais da Igreja}

Santidade. A espiritualidade bíblica dá sentido à vida comunitária e aos esforços de formação de comunidades. Trata-se de um novo modo de ser: eclesiologias que surgem da escuta da Palavra de Deus. Para a comunidade realmente agir na mesma linha de Jesus Cristo e seus apóstolos, há necessidade de uma atitude de submissão e de obediência à Palavra de Deus. Essa postura não se confunde com absolutismos fundamentalistas, mas é baseada em uma visão crítico-exegética, questionadora e libertadora, tendo como base a espiritualidade e a liberdade humanas.

A escuta da Palavra, como modo de vida eclesial, estabelece uma metodologia de comunhão, diálogo e disciplina. A Palavra de Deus não é ouvida individualisticamente, mas na escuta da/o irmã/o. Esta abertura de reconhecer no outro o caminho da Palavra, estabelece uma relação essencialmente comunitária. Na comunidade, ao ouvir a Palavra de Deus, as pessoas se encontram, se humanizam, se escutam. A vivência eclesial pos-

articulação adequada entre fé e razão e entre teoria e prática). 7. Utilidade para capacitar os membros da Igreja a estabelecer relações bem sucedidas com os de fora de seu grupo. As decorrências práticas desse processo de avaliação seriam: a. Modernização das estruturas eclesiásticas. b. Aproximação e intercâmbio ecumênicos. c. Pluralimso interno. d. Reforço da noção de provisoriedade dos projetos eclesiásticos. e. Liberdade e voluntariedade.

5 Cf. Paul Tillich. Systematic Theology III, pp. 182-206. Para mais detalhes, veja o que apresentei em "Para repensar a prática das igrejas: uma contribuição sistemática de Paul Tillich". Fragmentos de Cultura, 6(17), mai. 1996, pp. 39-48. 
sibilita o acompanhamento espiritual. Trata-se, não de relações verticalizadas, impositivas, conforme a realidade majoritária das igrejas no Brasil, mas, de diálogo e espaço de discernimento. As pessoas podem, por meio de seus carismas (portanto, não necessariamente clérigas, segundo o sacerdócio universal de todos os crentes), contribuir com as outras nos momentos de crise, decisões, caminhos a serem seguidos ou aprofundados.

$\mathrm{Na}$ comunidade também se vive a obediência Os elementos eclesiológicos da gratuidade, da liberdade e da espontaneidade nas relações não significam uma perspectiva sem referênciais. A obediência à Palavra, ouvida na comunhão e discernida no diálogo, é escuta interior que leva aos caminhos da solidariedade, em especial com os pobres e com os que sofrem. ${ }^{6}$

A dimensão eclesiástica das igrejas pode sufocar ou mesmo retardar o crescimento e o dinamismo da comunidade da fé se com seus aspectos jurídico-administrativos colocar limites para as ações livres e espontâneas. A Igreja, ao entender que ela não constitui o Reino, consegue escapar da tentação que a institucionalização provoca de tornar as comunidades fechadas em si mesmas e, como organismo vivo, revê permanentemente suas estruturas, modelos e formas de agir. A proposta mais adequada para o enfrentamento constante da igreja com os pensamentos que fogem do núcleo central da fé não é uma auto-definição, pois esta será sempre uma posição de auto-redução e fechamento. O que se requer é a retomada de um princípio fundante da visão teológica protestante que é realizar a constante reforma da igreja (ecclesia semper reformanda). Tal visão eclesiológica é receptiva a novas circunstâncias que por sua vez motivam novas atitudes. Assim, a ação renovadora da Igreja crítica e propositiva, se torna instrumento da nova ação de Deus na história

Unidade. A unidade faz parte da essência da Igreja e é condição sine qua non para a credibilidade do testemunho, da missão e do serviço. A unidade é um dom de Deus. Portanto, ela não é construída humanamente, mas as pessoas são chamadas a preservá-la com amor, humildade e man-

6 Como indiquei inicialmente em: "Diakonia: a comunidade como canal de solidariedade, partilha e serviço". Contexto Pastoral, 6(33) - suplemento Debate, jul/ago 1996, pp. 21-23. KOINONIA; "Por uma consciência ética na sociedade". Diálogo - Revista de Ensino Religioso (4), out 1996, pp. 11-15. Paulinas; "Nas fronteiras entre o público e o privado: aspectos da relação entre religião e cidadania" (pp. 113-128). In: VALLE, Lílian do (org.). O Mesmo e o Outro da Cidadania. Rio de Janeiro-RJ, DP \& A Editora, 2000. 
sidão como reconhecimento de que há um só corpo e um só Espírito, um só Senhor, uma só fé, um só batismo, um só Deus e Pai de todos, o qual é sobre todos, age por meio de todos e está em todos (Gálatas 4.1-16). O reconhecimento da diversidade e a preservação da unidade são essenciais para a edificação do corpo de Cristo e sinal de maturidade espiritual.

O espírito livre e flexível de abertura ao diálogo não significa que as diferenças não tenham que ser explicitadas. Somente a partir da explicitação honesta e franca das diferenças é que o diálogo pode produzir frutos duradouros que possibilitam manter a unidade. O diálogo sobre as divergências entre os membros do Corpo de Cristo fortalece a Igreja. Isto porque o diálogo, desde que desenvolvido em espírito de oração e comunhão com Deus, leva a descobertas que a cegueira produzida pela arrogância sectária, autoritária e auto-suficiente não permite enxergar (cf. o Concílio de Jerusalém, Gálatas 2. 9-10). Cumprir a missão de Deus implica em um diálogo prático e constante que leva à aceitação do outro. O diálogo deve ser amplo para ser ecumênico, aberto para ser eficaz e prático para gerar resultados para o Reino.

A perspectiva teológica da Igreja enfatiza a comunhão em, pelo menos, três aspectos: como exigência do Evangelho, com recurso pastoral para consolo mútuo, aperfeiçoamento comunitário da vida cristã e outras experiências fraternas, e visibilidade missionária, na medida em que a vida em comunidade constitui-se em si mesma, missão da Igreja.

Catolicidade. A catolicidade da Igreja está em contraposição ao exclusivismo religioso ou a outras formas de sectarismos. O NT destaca a pluralidade de modelos de organização da Igreja, o que significa afirmar que não existe "o" modelo bíblico, mas formas diferenciadas de ser Igreja. Essa não se restringe a grupo étnico, expressão cultural ou localização geográfica específica, mas está aberta "a judeus e gregos, escravos e livres, homens e mulheres” (Gálatas 3. 28), sendo universal em sua abrangência.

A universalidade pressupõe uma criativa tensão entre a variedade infinita de expressões de fé e de amor - marcas da Igreja - tanto nas diferenças pessoais como nas coletivas e institucionais. O que se preserva com a catolicidade da Igreja é que ela, antes de ser organização, instituição ou grupo social, é um Corpo, um organismo vivo, uma comunidade de fé, adoração, crescimento, testemunho, amor, apoio e serviço. 
Relacionado a essa visão está a perspectiva ecumênica. Ela é fundamental para todo e qualquer esforço teológico-pastoral. Esta visão quando vivenciada existencialmente e/ou assumida como elemento básico entre os objetivos, altera profundamente o desenvolvimento de qualquer projeto, iniciativa ou movimento. Em todos os campos da teologia, o dado ecumênico suscita novas e desafiantes questões.?

A teologia ecumênica tem formulado novas perspectivas. $O$ termo que talvez melhor expresse este panorama é a transconfessionalidade. Na proposta ecumênica não se trata de menosprezar as raízes confessionais. Ao contrário, busca-se nas raízes confessionais, os elementos positivos, singulares e que se mantêm como contribuição permanente. Ao mesmo tempo se descarta de cada confissão os elementos historicamente superados. Neste sentido, a proposta ecumênica, ao contrário de justapor ou articular confissões, concentra-se na busca coletiva dos valores da fé bíblica e para isso, transpõe as fronteiras confessionais e denominacionais. ${ }^{8}$

Os apelos bíblicos para a unidade são imperativos que desafiam constantemente as igrejas e todos os cristãos. A clássica expressão na oração de Jesus condiciona a vivência eclesial à unidade dos apóstolos: "a fim de que todos sejam um. Como tu, ó Pai, estás em mim e eu em ti, que eles estejam em nós, para que o mundo creia que tu me enviaste" (João 17). A vocação pela unidade, a abertura ao outro e o alargamento de horizontes são, acima de tudo, a primazia da fé em relação a lei. Desta forma, "não há judeu, nem grego, não há escravo nem livre, não há homem nem mulher; pois todos vós sois um só em Cristo Jesus" (Gálatas 3).

Apostolicidade. O Espírito Santo, como comunicador de Deus ao ser humano, impulsiona as comunidades a assumirem os princípios do Reino de Deus, em um processo de encarnação do Evangelho na história. O Espírito Santo é a força que lança a Igreja nascente "até os confins da terra" (Atos 1. 8) acompanha e guia a ação dos apóstolos (Atos 16. 6s). A Igreja, como nova criação, não pode nascer senão do Espírito, ao qual se deve tudo o que nasce de Deus.

Cf. "CEBs e Ecumenismo: uma discussão a partir da dimensão ecumênica do Oitavo Intereclesial”. publicado em Revista Eclesiástica Brasileira (REB), 52(208), dez 1992.

8 Cf. José Bittencourt Filho. Analisis Sociopolitico de la Marginalidad desde la Perspectiva Latino-americana. Consulta-Evaluacion del Processo São Paulo. Lago-Yojoa-Honduras, dez 1992. 
Catalisador da nova aliança, o Espírito, como prometido em Pentecostes, redimensiona para o presente a obra de Cristo, como defensor dos pobres, que assiste ao próximo e conduz o povo à santidade (Lucas 4). Segundo o testemunho bíblico, o chamado de Deus ao povo, exercido pelo Espírito, realiza-se por intermédio do cumprimento da justiça, da solidariedade e da busca da dignidade humana, na medida em que homens e mulheres exercitam a liberdade ("pois onde está o Espírito de Deus, aí está a liberdade") e a igualdade para benefício do todo. A espiritualidade, como vocação do Pai destinada a toda a criação, é a presença do Espírito Santo na vida humana, que faz com que as pessoas, comunidades e instituições caminhem a partir das referências do ministério de Cristo, em direção ao estabelecimento do amor e da justiça do Reino de Deus.

\section{Terceira pressuposição: a tensão entre instituição e movimento}

As questões "quem é a Igreja?", "onde está a Igreja?" e "quem fala pela Igreja" trazem à tona a tensão entre instituição e movimento ou, em outros termos, entre instituição e comunidade. O próprio fato da existência destas questões revela a existência de um novo discurso eclesiológico, portanto de uma crise, que se dá nos momentos de desequilíbrio - ou equilíbrio precário entre as instituições e as suas bases humanas. Rubem Alves indicou que

A função das instituições é fundamentalmente prática. Para viver e sobreviver temos de ser capazes de resolver problemas. Mas não é possível a cada geração aprender a resolver os seus problemas, da estaca zero. Nas instituições, a memória das soluções passadas é preservada. Na verdade, é possível dizer que as instituições são a memória inconsciente da sociedade. [ ]

De um lado, a instituição faz uso dos seus mecanismos para impor sua interpretação da realidade e os comportamentos correspondentes. Do outro lado, as pessoas, sentindo um mundo diferente e os problemas novos que resistem às programações institucionais, são obrigadas a se desviar das instituições. As instituições, que num momento originário foram criadas como 
expressão e instrumento de pessoas, passam a ser vividas como obstáculo e repressão. ${ }^{9}$

Indicação objetiva desta tensão foi o surgimento das Comunidades Eclesiais de Base, de grupos informais de vivência da fé (no interior da Igreja Católica ou ecumênicos), e outras e "novas formas de Igreja", nas décadas passadas. ${ }^{10}$

A comunidade é a nova realidade social a partir da qual se elabora uma nova eclesiologia. Essa realidade encontra-se dentro da própria instituição, pois ambas têm em perspectiva o mesmo horizonte simbólico. A tensão se dá na recusa da comunidade de ler os mesmos símbolos com as significações cristalizadas pela instituição. A comunidade se define em sua relação dialética e ambivalente com a instituição, e é uma criadora de significações. Trata-se como mais uma vez indicou Rubem Alves, de uma

dialética semelhante a que encontramos no Antigo Testamento entre o povo de Israel como nação e estado de um lado, e o 'remanescente', 'a santa semente', do outro. Semelhante, ainda à dialética entre sacerdotes e profetas. O sacerdote privilegia as significações funcionais às instituições. O profeta, entretanto privilegia as significações disfuncionais. O sacerdote deseja preservar o que já é. O profeta deseja que o novo seja criado. O primeiro constrói templos sobre o atual. O segundo constrói tendas, pois a sua consciência se abre para o possível. A comunidade se afirma fiel a uma vocação originária, que foi petrificada pela instituição. Ela deseja recuperar o carisma que criou a instituição e que foi por ela, posteriormente, eliminado. ${ }^{11}$

9 Rubem Alves. Dogmatismo e Tolerância. São Paulo-SP, Paulinas, 1982, pp. 40-1 e 45.

10 É amplíssima a bibliografia sobre as Comunidades Eclesiais de Base. Para uma avaliação histórico-teológica e de conjunto veja a trilogia de Faustino Luiz Couto Teixeira: $A$ Gênese das Ceb's no Brasil: elementos explicativos (São Paulo-SP, Paulinas, 1988), A Fé na Vida: um estudo teológico-pastoral sobre a experiência das Comunidades Eclesiais de Base no Brasil (São Paulo-SP, Loyola, 1987) e Comunidades Eclesiais de Base: bases teológicas (Petrópolis-RJ, Vozes, 1988). Veja também Comunidades Eclesiais de Base e Inculturação da Fé, de Marcelo Azevedo (São Paulo-SP, Loyola, 1986), As Comunidades de Base em Questão, de vários autores (São Paulo-SP, Paulinas, 1997) e O Código Genético das CEBs, organizada por William César de Andrade (São Leopoldo-RS, Oikos Ed., 2005).

11 Rubem Alves. Op. cit, p. 49. 
Considerando a ortodoxia e a supremacia institucional presentes nas igrejas tradicionais, a comunidade adquire por vezes, dimensões de heresia, isto é, na comunidade surgem vozes opostas no plano do poder - e não no plano da verdade. Estas rupturas impossibilitam um redizer da linguagem institucional ou mera reprodução (confissão) da doutrina. A busca e a construção de comunidades (ou vivência comunitária da fé) impõem uma nova linguagem. "Não se pode pensar numa comunidade nova falando uma linguagem velha". ${ }^{2}$

Um segundo aspecto é a liberdade de ação do Espírito de Deus, o qual sobrepõe-se até mesmo, às estruturas e aos condicionamentos institucionais. A comunidade, além de uma animação e dinamização da vivência institucional da Igreja (perspectiva reformista), emerge como novidade existencial e teológica da Igreja, e torna-se canal vivificador e alternativo quando o destino das instituições alcançar a morte (perspectiva de ruptura e renovação). "A morte também é parte da intenção do Espírito porque somente pela morte deixamos o espaço do presente e do futuro livre para as novas gerações". ${ }^{3}$ Esse quadro indica a necessidade de se vislumbrar respostas para a questão - crucial para a teologia e a fé cristã - "onde é que o poder de Deus está tomando forma social?".14

O terceiro aspecto subverte a eclesiologia clássica - com sua pressuposição de que todos sabem onde está a Igreja - ao abandonar as afirmações dogmáticas e ao assumir as indagações como metodologia pastoral e teológica. Se para os católicos a Igreja se encontra na unidade institucional cujo vértice é o Papa; se para os protestantes ela se encontra na reta confissão de fé; cabe diante da dialética entre instituição e comunidade, refazer a pergunta. Se as definições institucionais ou as cristalizações doutrinárias não constituem a marca distintiva da Igreja, onde ela está, afinal?

As marcas da Igreja têm a ver com a qualidade de vida que a comunidade produz..$^{15}$ Naturalmente, sua visibilidade dependerá dos referenciais éticos e utópicos de cada um. "O Reino de Deus é como o fermento es-

\footnotetext{
12 Ibidem, p. 50.

13 Ibidem, p. 51.

14 Idem. "A Missão da Igreja numa Era Apocalíptica: notas não objetivas sobre a Conferência de Bangcoque". CEI Suplemento (3), mar 1973, p.4.

15 Idem. Dogmatismo e Tolerância. Op. cit. p. 52.
} 
condido em três medidas de farinha, até a massa ficar levedada" (Lucas 16, 21). E algumas marcas estão presentes. Cotidianas, fragmentadas, combatidas, mas presentes entre as pessoas: o amor, o perdão, a liberdade, 0 respeito pela diferença e pelos caminhos comuns e a vivência da vida em sua concretude.

\section{Quarta pressuposição: o valor dos sacramentos}

O reconhecimento do valor dos sacramentos - dentro da tradição protestante: o Batismo e a Eucaristia - está associado a Palavra de Deus. Na perspectiva da teologia cristã, eles, como meios de graça, representam de maneira objetiva a graça de Cristo que confere o perdão dos pecados humanos. O poder sacramental é exclusivo de Deus que, por meio de sua Palavra, dá vida aos sinais externos de água, pão e vinho, evitando assim, formas de instrumentalização ou de idolatria dos sacramentos.

Não obstante as diferentes compreensões teológicas, os sacramentos são compreendidos como ordenança bíblica, fonte de renovação da fé, e experiência vital que não pode tornar-se sacramentalismo. A Eucaristia como sacramento do Evangelho, é expressão plena do amor do Pai revelado em Jesus Cristo pelo poder do Espírito Santo. Por intermédio dela, Deus introduz o povo aqui-e-agora, em seu amor perdoador e gracioso. Na Ceia do Senhor, a comunidade celebra a presença real do Cristo verdadeiro celebrante, que atualiza pela mediação do Espírito Santo a obra do Reino na vida humana. Por meio da celebração, o Senhor comunica a sua graça e motiva a unidade, a partilha, a solidariedade e o exercício da doação humana.

A celebração da Ceia vista como meio de graça demonstra de forma mais efetiva o seu caráter acolhedor e inclusivo. Ela não é um privilégio para alguns, mas um momento - aberto a todos que anseiam o favor divino - de perdão, adoção e recepção da comunhão com Deus e, conseqüentemente, entre irmãos e irmãs. Se o processo eclesial não articular as suas bases para que as mesmas estejam formadas no amor, a Igreja se tornará vazia de sentido excludente e alienada de sua real prática de fé. A celebração da Eucaristia traz ao povo referência do passado (a vida e a morte de Jesus Cristo), do presente (como a participação eclesial de todos/as no Espírito) e do futuro (como poder vislumbrar o sonho escatológico de justiça já evidenciado no ato criador do Pai). 
O Batismo, da mesma forma, é experiência de comunhão por excelência. Ele, relacionado à compreensão da salvação como renovação da imagem de Deus na humanidade, não é o fim, mas o meio pelo qual se atesta a graça de Deus. Ele destaca a pessoa para a herança das promessas da aliança estabelecida pelo Pai, a qual, por intermédio da ação reconciliadora do Espírito, ganha o seu ápice na possibilidade de se receber os benefícios da vida, da morte e da ressurreição de Jesus. Ao sinalizar a vida nova e abundante, o ato do Batismo revela à comunidade sinais de alegria e de prazer acompanhados de novas possibilidades de ação e de integração.

\section{Quinta pressuposição: a renovação da vida}

Nenhuma igreja se identifica automaticamente e sob todos os pontos de vista com a Igreja de Jesus Cristo. Somente com a Presença Espiritual (cf. Paul Tillich) ou sob a Palavra (cf. Karl Barth) a Igreja se constitui como tal. A Igreja é digna de fé somente quando, seguindo a Jesus, percorre o caminho como Igreja provisória, consciente de sua culpa e resoluta. ${ }^{16}$

A fraqueza da Igreja estará sempre quando o presente de sua fé perder a capacidade de testemunhar o passado e visualizar o futuro; ou mesmo em suas tentativas de realizar tais tarefas por sua própria força e capacidade.

A eclesialidade firmada no amor é um processo, cuja dinâmica é contínua e marcada por tensões. Tal eclesialidade pressupõe que o universo existencial de cada integrante da comunidade experimente a conversão, metanóia, uma nova concepção e atitude de vida. A exemplo da parábola do bom samaritano (Lucas 10, 25-37) - cuja indagação "qual destes três te parece ter sido o próximo do homem que caiu? (...)" possibilita a ruptura e uma decisão existencial - as pessoas em comunidade renascem para a vida. Trata-se do aparecimento do novo ser humano e de uma humanidade inteiramente nova.

A eclesialidade bíblica requer o aparecimento de pessoas fundamentalmente livres para criarem seu comportamento ante as exigências e possibilidades concretas deste mundo. No entanto, a comunidade sempre viverá em situação de perigo e de instabilidade porque sua missão de fazer justiça,

16 Cf. Karl Barth. Church Dogmatics. Vol. IV, 1. Edinburgh, T. \& T. Clark, 1956.

ReVISTA de Cultura TEOLÓGICA - V. 15 - N. 61 - oUt/DEZ $2007 \mathbf{1 1 5}$ 
ser luz no mundo e anunciar o domínio de Deus, será sempre questionada por outros domínios. A mensagem da Igreja é suficientemente revolucionária para criar uma reação - compreensível, uma vez que ela, nas palavras de Karl Barth, proclama uma nova humanidade e a necessidade de conversão discipulado e cruz.

\section{II - AJUSTAR O FOCO: UM OLHAR SOBRE A ECLESIOLOGIA POPULAR}

O aspecto prático da reflexão aqui proposta é a criação e o fortalecimento de vida comunitária, em função do potencial de geração de utopia encontrado nessa perspectiva. Pressupõe-se que a ausência de referenciais utópicos dá lugar a formas de imediatismos e absolutismos das realidades concretas da história, o que é fortemente negativo para a pastoral. A vida em comunidade, nesse sentido, é fonte saudável de utopia e, portanto, de potencial crítico às formas individualistas e idolátricas que têm marcado fortemente as igrejas nas últimas décadas.

Um dos pressupostos fundamentais da perspectiva teológica latino-americana é a vivência comunitária. ${ }^{17}$ Nesse sentido, encontra-se uma riqueza de difícil descrição no cotidiano e nas práticas efetivas das Comunidades Eclesiais de Base no contexto católico-romano e de grupos similares no campo protestante. ${ }^{18} \mathrm{~A}$ realidade de vida das pessoas e das famílias pobres, vivida

17 Sobre a eclesiologia latino-americana, veja, entre tantos títulos: BOFF, Leonardo. Igreja: Carisma e Poder: ensaios de eclesiologia militante. Petrópolis-RJ, Vozes, 1981; E a Igreja se fez povo - Eclesiogênese: a Igreja que nasce do povo. Petrópolis-RJ, Vozes, 1986; CODINA, Víctor. Para compreender a Eclesiologia a partir da América Latina. São Paulo-SP, Paulinas, 1993; COMBLIN, José. A Igreja e sua missão no Mundo. Breve Curso de Teologia - Tomo III. São Paulo-SP, Paulinas, 1985; O Povo de Deus. São Paulo-SP, Paulus, 2002; MUÑOZ, Ronaldo. A igreja no Povo: para uma eclesiologia latino-americana. Petrópolis-RJ, Vozes, 1985; RICHARD, Pablo. A força espiritual da Igreja dos pobres. Petrópolis-RJ, Vozes, 1989; SANTA ANA, Júlio. Pelas Trilhas do Mundo, a caminho do Reino. São Bernardo do CampoSP, Imprensa Metodista, 1985; SOBRINO, Jon. Ressurreição da verdadeira Igreja: os pobres, lugar teológico da eclesiologia. São Paulo-SP, Loyola, 1982; TORRES, Sérgio (org.). A Igreja que surge da Base: eclesiologia das comunidades cristãs de base. São Paulo-SP, Paulinas, 1980; MIGUEZ BONINO, José. Hacia uma Eclesiologia Evangelizadora: uma perspectiva wesleyana. São Bernardo do Campo-SP, Editeo/Ciemal, 2003.

18 A experiência como assessor das CEBs, tem me oferecido condições de acompanhar e refletir sobre várias experiências; todas de interpelação eclesiológica singular. Uma parte dessa experiência eu registrei em: "Um Encontro de Ecumenismo, Solidariedade e Esperança: $7^{\circ}$ Intereclesial de CEBs". Revista Eclesiástica Brasileira (REB), 49(195), jul/set 1989, pp. 
em meio ao sofrimento, à gratuidade e aos esforços políticos, têm sinalizado historicamente aspectos fundamentais do Reino. A partir da década de 1960, no Brasil e na América Latina em geral, isso se tornou elemento central de reflexão teológica. Todavia, as análises indicam, não obstante diferentes êxitos pastorais, algumas limitações para a vivência comunitária.

A forte racionalidade de teologias como a da Libertação ${ }^{19}$ por exemplo, tem feito - entre outros motivos - com que a pastoral perca sua amplitude popular e deixe paulatinamente de estar mergulhada na realidade da imensa maioria da população pobre e marginalizada socialmente. Por outro lado, a ressonância que os novos movimentos religiosos têm encontrado no universo existencial, cultural e simbólico do povo, desafia os setores da pastoral popular a criarem novas sínteses entre evangelização e cultura. ${ }^{20}$ Por outro lado, a vivência comunitária da fé, devido ao crescimento das experiências religiosas relacionadas as conhecidas ênfases da Teologia da Prosperidade

578-855. Vozes. [Também publicado em Tempo e Presença (243), jul 1989. CEDI]; "Novos Enfoques da Pastoral". Aconteceu no Mundo Evangélico, 9(86), jul 1990. CEDI; "Por uma Nova Forma de Ser". Contexto Pastoral, 1(0), fev/mar 1991. CEDI/CEBEP; "Cebs e Ecumenismo: uma discussão a partir da dimensão ecumênica do Oitavo Intereclesial". Revista Eclesiástica Brasileira (REB), 52(208), dez 1992, pp. 846-855; "Evangélicos e Comunidade de Base: um namoro promissor?" Contexto Pastoral, 2(11), nov/dez 1992; "CEBs: passos e impasses". Contexto Pastoral, 6(32), mai/jun 1996, p. 5. KOINONIA; "O novo jeito de ser da 'nova forma de ser igreja". Contexto Pastoral, 6(39), jul/ago 1997, p. 3; "Caminhar juntos: um balanço da trajetória ecumênica das CEBs no Brasil". Revista Eclesiástica Brasileira (REB), 57(228), dez 1997, pp. 867-880 (esse, em conjunto com Jether Pereira Ramalho). Veja também Os Encontros Intereclesiais de CEB's no Brasil (São Paulo-SP, Paulinas, 1996), de Faustino Teixeira.

19 Fiz essa análise em vários momentos. Veja, especialmente: "A Teologia da Libertação Morreu? Um panorama da Teologia Latino-Americana da Libertação e questões para aprofundar o debate teológico na entrada do milênio". Revista Eclesiástica Brasileira, 63(250), abril 2003, pp. 320-353; "Una terra per la TdL: La Teologia della Liberazione al tempo del neoliberismo". Adista (86) - Contesti (10), Nov. 1999, pp. 2-8; "Novos Desafios para um Novo Milênio: reflexões em torno da teologia e da pastoral latino-americanas". Perspectiva Teológica, 27(72). Cia. de Jesus, mai/ago 1995; "A difícil arte da revisão". Ipsis Verbis, 2(2), jun 1995/mai 1996, pp. 4-5. KOINONIA; "Mudanças e Desafios: a pastoral e a teologia latinoamericanas em questão". Revista de Cultura Teológica, 3(12), jul-set 1995. Faculdade de Teologia N.S. Assunção; "Nuevos Desafios para un Nuevo Milenio: Reflexiones en torno de la Teologia y de la Pastoral Latino-americana". Selecciones de Teologia, Vol. 38(150), 1999, pp. 107-119. Facultad de Teología Catalunya; "Has Liberation Theology Died? Reflections on the Relationship between Community Life and the globalization of the Economic System". The Ecumenical Review, 51(3), July 1999, pp. 304-314; e "O que um Cristão precisa saber sobre a Teologia da Prosperidade?" Caminhando, 12(19), pp.41-56.

20 Como indiquei em "Pluralidade e Gratuidade: caminho para o debate entre evangelização e cultura". Tempo e Presença, 14(262), mar/abr 1992. CEDI. 
e similares, têm cedido lugar as propostas de massa, com ênfase no uso e no consumo de discos, camisetas, slogans e imagens de pessoas, e no reforço ao individualismo e à intolerância.

Quais seriam portanto, os desafios prático-pastorais diante dessa realidade? Como revitalizar fontes de utopia? Qual o lugar da vida comunitária nesse processo?

Para essa reflexão serão destacadas as seguintes dimensões: koinonia (a comunidade como lugar fraterno), diálogo (a comunidade como espaço de autenticidade), utopia (a comunidade como espaço de expressão devocional e lúdica), diakonia (a comunidade como canal de solidariedade, partilha e serviço). Tais aspectos são o reconhecimento de que a vida em comunidade, por ser fonte privilegiada de utopia, se torna em elemento de combate às diferentes formas sectárias, violentas, individualistas ou idolátricas do agir humano, e nos leva a exercer a vontade de Deus no mundo.

\section{A comunidade como lugar privilegiado de comunhão}

A dificuldade de relacionamento humano tem sido uma das características da atualidade. Isso vem atingindo toda a sociedade, mas a situação das famílias pobres é, de modo especial, conflitiva, por razões históricas e estruturais.

Os aspectos violentos da falta de infra-estrutura social se refletem visivelmente nas igrejas. As reuniões eclesiásticas, em termos metafóricos, tornam-se muitas vezes um fratricídio uma vez que a visão sectária - fruto das diferentes formas de pietismo, tanto no contexto católico como no protestante - as muitas divisões internas e a burocracia pastoral geram fortes disputas e tensões entre os membros das igrejas.

Todavia, a experiência concreta vivida pelas comunidades - ainda que com distorções - apontam para uma koinonia. Também é notório que os elementos de festividade, alegria, emocionalidade e abertura - intensamente presentes na matriz cultural e religiosa do povo brasileiro - cooperam para essa possibilidade.

O pressuposto dessa concepção é que o amor não é próprio das comunidades, na medida em que "nós nos amamos porque Deus nos amou primeiro" (I João 4.19). Ele constrói a comunidade em amor, a qual é a reunião 
daqueles que, sob a ação do Espírito Santo, Jesus tem tornado dispostos e prontos para a experiência da plenitude da vida. É a realização subjetiva do que objetivamente ocorreu com Cristo em sua morte e ressurreição.

Há uma série de implicações pastorais decorrentes dessa concepção teológica. Os limites desse texto não possibilitam uma reflexão mais abrangente e detalhada. A espiritualidade bíblica reconstrói a vivência eclesial, pois a institucionalidade da Igreja não garante a comunhão. A compreensão bíblico-teológica é de que a Igreja, em si mesma, não é santa. Ela partilha, como comunidade do Espírito entre a humanidade, seus pecados e sua culpa, e coloca-se absolutamente na necessidade de sua justificação em Cristo.

O que a realidade das igrejas tem indicado, ainda que de forma caricata, é que as suas tendências teológicas ${ }^{21}$ não consideram a comunhão eclesial como valor. Ou seja, por si mesma a comunhão da Igreja não é um objetivo - ou, na melhor das hipóteses, está bem abaixo na escala de preocupações e de prioridades pastorais. Aos "conservadores", interessa a estabilidade institucional e doutrinária; aos "carismáticos" convém outra formulação dessa doutrina; aos "progressistas" importa o engajamento político-social (cf. I Coríntios 12.12-31). Mas, quem irá cuidar do amor e da unidade eclesial? A mensagem neotestamentária desafia as igrejas à sua vocação de unidade: "Com toda humildade e mansidão, com longanimidade, suportando-vos uns aos outros em amor, esforçando-vos diligentemente por preservar a unidade do Espírito no vínculo da paz" (Efésios 4.1-6).

A perspectiva não é minimizar o engajamento político-social ou a discussão doutrinária. $\mathrm{O}$ que se busca é uma espiritualidade para essas demandas que não seja artificial, como por vezes encontrada nos movimentos "carismáticos", ou racionalistas, como nos setores "conservadores" e "progressistas". A eficiência deve estar num contexto profundo e plenamente humano - espaço de um encontro gratuito com o Senhor - transformandose em eficácia.

21 Estamos seguindo a distinção comum que indica a presença de três grupos com perspectivas teológico-doutrinárias distintas no interior das igrejas: "conservadores" (associados historicamente à visão burocrática e tradicionalista), "carismáticos" (reação ao primeiro grupo a partir de ênfases cúlticas e doutrinárias próprias da experiência pentecostal) e "progressistas" (reação também ao primeiro grupo, a partir da ênfase na responsabilidade social e política da Igreja). Veja: MATTOS, Paulo Ayres. Pastoral Metodista: ontem, hoje, amanhã. São Bernardo do Campo, FTIM/IMS, 1987. 
Ao se considerar a realidade uma das lacunas, encontra-se na insensibilidade pastoral para tratar dos conflitos, de tal maneira que possam ser canalizados para uma vivência fraterna. As igrejas caracterizam-se em geral pela generalidade em seu discurso e por um dualismo que advogam para si o lugar do bem. Na maioria das vezes, no campo pastoral, o ponto de partida é um idealismo, ao considerar a igreja como lugar de intensa fraternidade e amor, e não se desce a sua realidade conflituosa. Quando o ponto de partida são os próprios conflitos existentes, não há abalos psicológicos em demasia ao se defrontar com eles e, na superação, gera-se um estado de alegria e de satisfação (cf. Rm 12, 9-21).

A comunidade, se forem realçadas suas possibilidades de exercício da comunhão, é uma experiência antecipada da plenitude do Reino de Deus. Da mesma forma que a comunidade primeira dos cristãos se sentia feliz em partilhar os bens e se amar (cf. Atos 2.43-47; 4.32-37), hoje também é possível se amar-partilhar. Há, portanto, uma espiritualidade que dá sentido a vida comunitária e aos esforços de formação de comunidades. ${ }^{22}$

\section{A comunidade como espaço de diálogo e de autenticidade}

As exigências evangélicas realizadas por Jesus (gratuidade, diálogo, personalização, crítica) caracterizam-se por ser uma "conduta minoritária". Todavia, a proposta evangélica não pode desejar o "minoritário" como alvo, transformando-a em um novo tipo de lei. Na proposta do Evangelho, o interesse pelas massas é fundamental para que novas e criativas sínteses entre o dom da fé que vem de Deus e as experiências humanas, venham a ocorrer. No entanto, por outro lado, a atenção e a fidelidade ao núcleo

22 Sobre espiritualidade e vivência comunitária da fé, veja alguns ensaios que apresentei: "A espiritualidade entre a libertação e a gratuidade". Contexto Pastoral, 5(24), jan/fev 1995. KOINONIA/CEBEP; "Experiência Carismática, vírgula...". Contexto Pastoral, 3(16), set/out 1993; "A Mística e o Incondicional". Contexto Pastoral, 5(28), set/out 1995; "Carta a Karl Barth". Contexto Pastoral, 3(12), jan/fev 1993; "Viver na força do Espírito". Contexto Pastoral, 6(30), jan/fev 1996, p. 9; "Liturgia e ecumenismo". Revista de Liturgia, 24(141), mai/jun 1997, pp. 4-6. Paulinas; "Movimentos pentecostais, carismáticos e mística cristã: desafios teológicos e pastorais". Perspectiva Teológica, 28(76), set/dez 1996, pp. 339-364. Cia. de Jesus; e "Falar e Calar: reflexões a partir da leitura do livro de Jó efetuada por Gustavo Gutierrez". Revista de Cultura Teológica, 7(27), abr/jun 1999, pp. 87-99. 
central do Evangelho, devido ao seu caráter exigente podem não possuir aceitação massiva. ${ }^{23}$

A eclesiologia que compreende a vida em comunidade como fonte de utopia requer esforços pastorais específicos. Nesse sentido, por exemplo no aspecto litúrgico é necessário, entre outros, dar uma dimensão mais criativa e menos rotineira à celebração da Eucaristia, enfatizar que ela é comunhão entre irmãos e que não importam as ênfases moralistas e legalistas da prática das igrejas.

No aspecto político, é necessário distender as relações clérigos-leigos, recuperar a dimensão diaconal e criar discursos pastorais com maior transparência. Não se trata de práticas demagógicas ou populistas, mas eclesialmente os agentes pastorais precisam estabelecer uma relação mais harmônica e fraterna com os membros da igreja.

É comum entre clérigos e comunidades, um autêntico embate: para que a igreja se torne "progressista"; para pentecostalizar a igreja; ou para não permitir essas duas coisas. No entanto, o que é necessário é a conjugação de esforços teológico-pastorais para a comunidade local ser ela mesma; ou seja, é preciso haver mediações para que as pessoas falem o que pensam, ouçam os irmãos e irmãs e tirem conclusões que as façam crescer na fé. A possibilidade de as pessoas serem elas mesmas (autenticidade) e poderem falar, ouvir, concluir (maturidade) é uma fonte rica de felicidade e de utopia.

Outros e diferentes exemplos podem ser listados ou deduzidos a partir desses. A criatividade pastoral própria do contexto latino-americano e uma perspectiva teológica propositiva parecem formar uma composição de potencial ainda não totalmente mensurado.

\section{A comunidade como espaço de expressão devocional e lúdica}

Para as reflexões acerca de uma eclesiologia popular e sobre os modelos de ação pastoral entre os empobrecidos, um fato que tem sido chamado a

23 Veja as conhecidas teses de Juan Luis Segundo em Massas e Minorias: na Dialética Divina da Libertação. São Paulo-SP, Loyola, 1975. Sobre uma 'pastoral de massas', veja: a obra Igreja: Comunidade e Massa, organizada por Ivo Lesbaupin (São Paulo-SP, Paulinas, 1996). 
atenção é a violência do discurso pastoral politizado diante da expectativa religiosa dos que vão à igreja. ${ }^{24}$ Quanto a isso, diante das referências teológicas anteriormente apresentadas, pode-se advogar, sem receios, que a comunidade local seja uma "bolha" na qual os membros podem sentir-se "bem em flutuar um pouco acima de sua realidade". No entanto, em função das mesmas referências teológicas, é necessário distinguir qual o limite entre essa perspectiva e as práticas alienantes que marcam as vivências no interior das igrejas, especialmente as relacionadas com as formas religiosas intimistas e sectárias.

A primeira negação a ser feita é a "pastoral de sucesso". Regra geral, há maior compromisso do clérigo com a instituição do que com a comunidade local e seus desafios. Acompanhando tendências conjunturais de carismatização das igrejas, tem sido comum lideranças avessas a essa experiência tornarem-se artificialmente "carismáticas", no intuito de adequar-se às expectativas majoritárias ou em ascensão em suas comunidades.

Outra negação necessária é a total evasão do mundo como felicidade, como tem sido historicamente a pregação das igrejas no Brasil; ou mesmo a fuga das explicações mais racionais e científicas das vicissitudes da vida. Esse é um aspecto complexo que acrescenta uma série de questionamentos à prática pastoral, por sua vez já complexa. Porque se as pessoas não podem fugir totalmente de suas realidades, por outro lado, encará-las é uma difícil tarefa, devido ao elevado grau de sofrimento e de degradação da vida humana na atualidade.

No campo da pastoral popular é impressionante a precariedade na qualidade de vida das pessoas. A maioria tem a saúde mental debilitada; os problemas familiares e existenciais são diversos; a vida material é desumana: moradias minúsculas, insegurança no trabalho, pouco ou nenhum lazer. Diante disso, são necessários uma pastoral e esforços litúrgicos de "consolação", mas em boa parte das vezes, ao menos nos ambientes orientados pela perspectiva da libertação, a ênfase encontra-se somente na "pastoral da transformação".

Como propor projetos/empenho/reflexões/estudos/reuniões em meio a tanto sofrimento? Será possível que um deslocamento um pouco acima da

24 Cf. SCHWANTES, Milton. "Toda a Criação Geme e Suporta Angústias". Tempo e Presença, 11(246), out. 1989, pp. 29-30. 
realidade possa ajudar a enfrentá-la? Ou a fé e a vivência eclesial estão confinadas a serem uma completa fuga de tudo?

Para uma renovação eclesial e litúrgica que leve em conta essa tensão, algumas indicações são bastante propícias. No culto, a Igreja realiza a communio sanctorum numa forma definida. Ele redimensiona o presente, ao não se confundir com o viver diário, seja do mundo, seja da própria comunidade, e a Igreja adquire sua natureza profética e escatológica. A experiência da salvação é o direcionamento da vida ao Reino de Deus, ao questionar e desestabilizar a realidade presente. $O$ futuro antecipado pela compreensão utópica cria com a dimensão lúdica, outro tipo de relacionamento com a realidade. O lúdico é uma forma de contestação e de desestabilização do presente, e sinaliza a infinitude e a misericórdia de Deus na subversão do real. ${ }^{25}$

As propostas politizadas que normalmente são apresentadas às igrejas (análises de conjuntura, debates, participação em associações, sindicatos e partidos) precisam estar presentes, pois são instrumentos da missão e ajudam a viver. Ver racionalmente o mundo e entender suas engrenagens sociopolíticas e econômicas são aspectos fundamentais da vida e da fé. No entanto, ao mesmo tempo, a comunidade local precisa ser o lugar de prazer onde ela ora, canta e cultua a Deus. Um espaço de "felicidade que não signifique a evasão do mundo, mas que ao mesmo tempo, viva na dimensão constante da transcendência do mistério, de onde brotam os contornos de toda experiência que comece a responder aos anseios infinitos do coração". ${ }^{26}$

Outro aspecto eclesial muito agradável, são as festas. Quanto mais festa, mais senso de comunidade, mais trabalho partilhado, mais alegria e comunhão, mesmo em meio à dor. ${ }^{27}$ As manifestações da cultura não podem ser reduzidas pelo olhar ortodoxo das ciências ou da pastoral. Isso já ocorreu com os modelos de organização popular no Brasil e redundou em

25 Cf. VELASQUES FILHO, Prócoro. "A Salvação como engajamento no processo de abertura para o futuro: a libertação e a celebração da vida". Ciências da Religião, 1(1) (A Vida em Meio à Morte num país do Terceiro Mundo). São Paulo-SP, Paulinas, jun. 1983, p. 168.

26 IDÍGORAS, J. L. Vocabulário Teológico para a América Latina. São Paulo-SP, Paulinas, 1983, p. 163.

27 Para melhores indicações teológicas veja a conhecida obra de Harvey Cox: A Festa dos Foliões: um ensaio teológico sobre festividade e fantasia. Petrópolis-RJ, Vozes, 1974; e a de Jean Vanier: Comunidade: Iugar do perdão e da festa. São Paulo-SP, Paulinas, 1995. 
sérios danos tanto à prática política dos grupos orientados pelos referenciais de esquerda, como a produção teológica e a pastoral popular no Brasil.

As festas, a ruptura irônica e criativa com os padrões sociais, as celebrações, o prazer, as devoções, o cotidiano - sofrido e alegre - revelam o papel da dimensão lúdica na existência humana. E tal é a novidade (Evangelho) - sem a necessidade de instrumentalização - que surgem daí reforço de identidade, socialização e um refazer da vida com novas utopias e dignidade.

\section{A comunidade como canal de solidariedade, partilha e serviço}

A missão de Deus requer uma organização eclesial cujo caráter comunitário deve promover um aprofundamento da fé cristã, de tal forma que ela não seja reduzida a "convicções teóricas" (intelectualismos) ou a "costumes exteriores" (moralismos). A missão também requer um estilo de vida pessoal e comunitário, marcado pelo despojamento e pela ação solidária, conforme as perspectivas da teologia latino-americana indicam. Uma eclesiologia brasileira precisa conter essa visão missionária necessariamente.

A missão tem como fundamento a noção do "mundo como espaço do Reino de Deus"28. Tal noção está relacionada a doutrina da santificação que, como se sabe, vai além da vida pessoal e inclui os aspectos da realização parcial e fragmentária do Reino no presente da vida humana, da história , do cosmo e reforça assim, a responsabilidade social cristã.

A partir dessa visão teológica e de outros referenciais importantes para o contexto brasileiro, temos refletido sobre o sentido diakonal da vida cristã. A diakonia, como dimensão eclesial, permite uma síntese da vivência de fé comprometida com os desafios da realidade social e política com aquela de maior apelo devocional e religioso. Ela ajuda os grupos a olharem para fora de si mesmos e não se conformarem com a realidade (Cf. Romanos 12, 1-2). Além disso, como são grandes os desafios, a dimensão ecumênica é reforçada e abrem-se novos canais para a unidade da Igreja.

28 KLAIBER, Walter \& MARQUARDT, Manfred. Viver a Graça de Deus: um compêndio de Teologia Metodista. São Bernardo do Campo-SP, Editeo/Cedro,1999. 
A comunidade que olha somente para si, perguntará sempre como Tiago e João - os filhos de Zebedeu: se podem na glória de Cristo, sentar-se um à direita e outro à esquerda. Mas, Jesus os desafia: "Entre vós não é assim; pelo contrário, quem quiser tornar-se grande entre vós, será este o que vos sirva e quem quiser ser o primeiro entre vós, será servo de todos" (Marcos 10, 35-45).

O critério da diakonia firma-se na resposta solidária às demandas concretas criadas em torno do sofrimento humano. Essas alcançam enormes proporções quantitativa e qualitativamente, o que significa dizer que os esforços e métodos necessitam ser plurais. Essa dimensão de ecumenicidade das ações solidárias e de serviço possibilita, portanto ações inclusivas de cristãos e não-cristãos, além de tantos outros, cuja situação de exclusão não lhes permite atuar em espaços formais, eclesiásticos ou burocráticos. A diakonia baseia-se essencialmente nos valores evangélicos e pode ser vivenciada tanto nos espaços orgânicos e de maior institucionalidade como na dispersão e na diáspora da vida humana e do exercício religioso da fé.

\section{À GUISA DE CONFISSÃO}

Escrever estas palavras poderia ser tarefa simples se não fosse a conseqüente necessidade de contribuir para torná-las uma realidade cada vez mais presente. Não se trata de negar todo o ambiente de gratuidade que envolveu essas páginas; nem de pensar que é possível chegar a Deus por esforços próprios. Mas, significa confessar a disposição de seguir a trilha do Espírito na reconstrução da vida.

Todavia, nem seria necessário afirmar que a dedicação pastoral nem sempre possui a intensidade que as demandas da ação missionária requerem; que o espírito fraterno e de compreensão nem sempre é exercido, a solidariedade, a partilha e a diversidade, não são valorizadas em todas as circunstâncias; e entro na igreja muitas vezes pela "mesma porta".

Estas noções acerca da vida das igrejas visaram cooperar para uma aproximação entre as discussões teóricas/teológicas e as atuais demandas pastorais. É preciso que, na diversidade de contextos nos quais encontramse pastores, pastoras, padres, lideranças leigas e outros agentes educativos envolvidos na dinâmica eclesial e política surjam formulações práticas destas idéias. 
O campo percorrido envolve praticamente toda a vida e ação da Igreja. Portanto, cada linha poderia se multiplicar em novas questões, debates, conversas e outros textos. Para a prática pastoral latino-americana, tanto no ambiente católico como no protestante, o aprofundamento dessas questões constitui tarefa oportuna e bastante pertinente, uma vez que tais ambientes se encontram em forte crise teológica e pastoral. Por outro lado, iniciativas desta natureza implicam sempre risco, assim como toda abertura a Presença Espiritual, ao Deus vivo, encarnado, mas "Totalmente Outro".

Ao longo dessa reflexão, um objetivo esteve presente: pensar teológicamente e pastoralmente a criação e o fortalecimento de vida comunitária. Pressupõe-se que a vivência comunitária constitui privilegiado potencial de geração de utopia e que a ausência de referenciais utópicos dá lugar a formas de individualismos exacerbados, de imediatismos políticos, de racionalismos e de absolutismos, o que enfraquece as igrejas.

Ao lado das referências teológicas, foram apresentadas algumas indicações pastorais em torno da vida em comunidade. As dimensões destacadas foram a de koinonia, a qual realça a comunidade como lugar fraterno, do diálogo, que compreende a comunidade como espaço de autenticidade, de utopia, que destaca a importância da dimensão lúdica e devocional e de diakonia, que vê a comunidade como espaço de serviço, de solidariedade e de construção de novos contornos sociais.

É fato, que os aspectos analisados não esgotam as implicações teóricas e práticas decorrentes da reflexão sobre a Igreja. Todavia, procurou-se indicar pelo menos as questões que parecem ser fundamentais, tendo em vista uma eclesiologia bíblica. Os pontos em debate visaram dar visibilidade às práticas que confirmam ou remontam a essa perspectiva para que, a partir de indicações teológicas e pastorais, busquem novas formas de ação e de reflexão, considerando sempre as peculiaridades do contexto brasileiro e latino-americano em geral em suas diferentes dimensões.

\section{BIBLIOGRAFIA PRINCIPAL}

ALVES, Rubem. Dogmatismo e Tolerância. São Paulo-SP, Paulinas, 1982.

BARTH, Karl. Church Dogmatics. Vol. IV, 1. Edinburgh, T. \& T. Clark, 1956.

BOFF, Leonardo. Igreja: Carisma e Poder: ensaios de eclesiologia militante.

Petrópolis-RJ, Vozes, 1981. 
CODINA, Víctor. Para compreender a Eclesiologia a partir da América Latina. São Paulo-SP, Paulinas, 1993.

COMBLIN, José. O Povo de Deus. São Paulo-SP, Paulus, 2002.

KLAIBER, Walter \& MARQUARDT, Manfred. Viver a Graça de Deus: um compêndio de Teologia Metodista. São Bernardo do Campo-SP, Editeo/Cedro,1999.

MIGUEZ-BONINO, José. Hacia uma Eclesiologia Evangelizadora: uma perspectiva wesleyana. São Bernardo do Campo-SP, Editeo/Ciemal, 2003.

SANTA ANA, Júlio. Pelas Trilhas do Mundo, a caminho do Reino. São Bernardo do Campo-SP, Imprensa Metodista, 1985.

SOBRINO, Jon. Ressurreição da verdadeira Igreja: os pobres, lugar teológico da eclesiologia. São Paulo-SP, Loyola, 1982.

TILLICH, Paul. Systematic Theology. Vol. III. Chicago-USA, The University Chicago Press, 1963.

\section{Prof. Dr. Claudio de Oliveira Ribeiro}

Pastor metodista na comunidade de Jardim Santo André e professor de teologia da Universidade Metodista de São Paulo. 